\title{
Struktur dan Ideologi Teenlit Karya Dyan Nuranindya
}

\author{
Titi Wuryani $^{1)}$, Agus Nuryatin ${ }^{2)}$, Mimi Mulyani ${ }^{3)}$ \\ 1. MA NU 06 Cepiring, Kendal, Indonesia \\ E-mail: wuryani.titi@gmail.com \\ 2. Universitas Negeri Semarang, Indonesia \\ E-mail: anuryatin@yahoo.co.id \\ 3. Universitas Negeri Semarang, Indonesia \\ E-mail: mimimulyani62@mail.unnes.ac.id
}

\begin{abstract}
This study aims to describe the structure and ideology of Dyan Nuranindya's work. There are six teenlit works by Dyan Nuranindya, namely Dealova, Star Secret, Canting Cantiq, Cinderela Pink Hair, Rock N Roll Onthel, and Kotak Pelangi. The method used in this research is descriptive analysis and dialectic which is also part of the approach of theory of genetic structuralism. The data in the study of the parts of the text in the form of words, phrases or sentences related to the genetic structure, ideology in the work of Dyan Nuranindya's work. The results showed the structure of literary works by Dyan Nuranindya's literature includes hero store relationships with other figures, and oposional relations. Relation of hero characters with other characters include brother's sister relation, parent's relation with child, love relation, oposional relation. The ideology contained in the work of Dyan Nuranindya's work is to achieve the ideals, love the homeland, preserve nature.
\end{abstract}

Keywords: structure; ideology; teenlit

\section{PENDAHULUAN}

Dilihat dari tema, dan bahasa teenlit, teenlit merupakan jenis sastra populer. Sastra populer bersifat mengabdi atau mengikuti selera pembaca. Jenis bacaan seperti ini mengalami pergantian selera setiap zamannya. Salah satu ciri sastra populer bertujuan untuk menghibur sehingga sering disebut sebagai bacaan hiburan. Ciri-ciri novel populer di antaranya banyak diterbitkan, dibaca secara luas, lekas terjual pada masanya, dan ditulis untuk diperdagangkan dengan penyajian yang siap saji (Sumardjo, 1982:110). Sastra populer dapat dijadikan gambaran kebudayaan masyarakat tertentu pada masa tertentu. Sastra popular dapat dijadikan sebagai petunjuk tentang apa yang menjadi anggapan umum masyarakat kota pada suatu masa.

Teenlit merupakan sebuah perkembangan baru dalam kesusastraan Indonesia. Fenomena teenlit menyajikan kesegaran baru dalam kaitannya dengan tema dan standarisasi buku-buku cerita yang mudah dipahami pembaca terutama di kalangan remaja. Teenlit dapat didefinisikan sebagai bacaan untuk mereka yang berusia antara 13 hingga 19 tahun. Teenlit menjadi sastra populer yang menarik karena upaya eksperimentatif dan eksploratif seperti yang dilakukan Dyan Nuranindya, yang menulis novel remaja sejak tahun 2004 sampai tahun 2016. Selama kurun waktu empat belas tahun telah menulis tujuh teenlit. Empat judul menjadi best seller karena dicetak ulang lebih dari lima kali. Empat judul novel best seller tersebut adalah Dealova (2004), Rahasia Bintang (2006), Canting Cantiq (2009), dan Cinderella Rambut Pink (2010). Salah satu eksploratif Dyan dalam menulis teenlit dengan tema persahabatan anak kos yang berlatar di Jogyakarta yang kemudian dijadikan tetralogi.

Teenlit karya Dyan Nuranindya perlu dikaji dari struktur dan kekhasan teenlit. Dua teenlit karya Dyan Nuranindya yaitu Dealova dan Rahasia Bintang menceritakan kehidupan anak SMA di Jakarta. Empat teenlit yang Dyan Nuranindya tulis merupakan sebuah tetralogi yang berlatar di Daerah Istimewa Yogyakarta yaitu, Canting Cantiq, Cinderella Rambut Pink, Rock n Roll Onthel, dan Kotak Pelangi. Selain dikaji dari segi struktur, teenlit karya Dyan Nuranindya dapat dikaji dari segi ideologi. Secara sosiologis teenlit karya Dyan Nuranindya memiliki ideologi yang ingin disampaikan pengarang kepada pembaca. Teenlit karya Dyan Nuranindya membangun pencitraan remaja perkotaan yang sukses dalam meraih cita-cita meskipun banyak halangan dan rintangan. Atas dasar itu maka penelitian ini memfokuskan pada struktur dan idelogi teenlit. 
Artikel ini memiliki tujuan mendiskripsikan struktur dan ideologi teenlit karya Dyan Nuranindya.

Peneliti ini memiliki relevansi Penelitian ini memiliki relevansi dengan penelitian sebelumnya terkait teenlit. Penelitian milik Noor (2014) dengan judul "Profil Penerbit Novel Chicklit dan Teenlit Indonesia". Dalam penelitian tersebut mengkaji tentang profil penerbit karya sastra terutama Chicklit dan teenlit. Dalam penerbitan berarti berurusan dengan hukum (sistem, mekanisme, dan strategi) yang diberlakukan oleh institusi yang memproduksi, yaitu penerbit. Oleh karena itu, lembaga penerbit (chicklit novel dan teenlit) akan membuat undang-undang industri yang khas, yang berbeda dengan hukum lembaga penerbit lainnya. Sistem dan mekanisme produksi chicklit dan novel Teenlit terdiri dari profil penerbit, akuisisi naskah (rekrutmen), pengeditan naskah (editing), dan distribusi naskah (distribusi). Profil penayang mencakup riwayat penayang, spesifikasi penerbit dan diversifikasi produk, serta kontak penerbit. Dalam komunikasi bisnis modern, identitas penerbit sama pentingnya dengan identitas produk. Kepercayaan konsumen dibangun melalui gambar penggambaran produk dan publisher, sehingga profil publisher menjadi acuan utama konsumen. Oleh karena itu, dalam deskripsi profil penerbit, ia selalu menekankan pengalaman keunggulannya (sejarah) dalam menerbitkan jenis novel seperti yang disebutkan sebelumnya, spesifikasi dan fitur produk yang mereka hasilkan, serta alat dan mekanisme modern-produksi mekanisme (pekerja kualifikasi, mesin cetak, manajemen). Sehubungan dengan profil penerbit, beberapa penerbit, Elex Media Komputindo, Gagas Media, dan Gramedia Pustaka Utama, telah merancang dan mempresentasikan secara unik (jujur, cerdas, dan "gantung") dan meyakinkan masyarakat pembaca, terutama pembaca remaja dan chicklit novel.

Strukturalisme genetik memiliki implikasi yang lebih dalam kaitannya dengan perkembangan ilmu-ilmu kemanusiaan pada umumnya (Ratna, 2009:122). Sebuah struktur, harus disempurnakan agar memiliki makna, di mana setiap gejala memiliki arti apabila dikaitkan dengan struktur yang lebih luas, demikian seterusnya hingga setiap unsur menopang totalitasnya.

Ideologi sebagai sebuah representasi dari hubungan imajinasi individu dengan kondisi yang baik dan mempunyai eksistensi. Ideologi selalu bersifat menginterpretasi individu menjadi subjek (individu yang melakukan pekerjaan) konkret dalam kesehariannya. Individu yang terpengaruh ideologinya, akhirnya mewujudkan diri sebagai subjek konkret untuk mengikuti apa yang diinginkan oleh ideologi tersebut. Ideologi dan sastra pada menggambarkan ideologi sebagai penyajian hubungan individu yang khayal kepada kondisi-kondisi keberadaan riil mereka (Althusser, 1971:159).

\section{METODE}

Metode yang digunakan dalam penelitian ini adalah deskriptif analisis dan dialektis yang juga merupakan bagian dari pendekatan teori strukturalisme genetik. metode deskripstif meneliti status kelompok manusia, suatu objek atau pun peristiwa. Tujuan metode deskripstif adalah untuk menggambarkan secara sistematis, faktual dan akurat mengenai objek yang diteliti. Analisis penelitian menggunakan kerangka teoretis yang ada dalam strukturalisme genetic Lucien Goldmann.

objek penelitian adalah teenlit karya Dyan Nuranindya yang menggambarkan remaja perkotaan. Secara teori novel tersebut dapat dikaji berdasarkan struktururalisme genetik. Analisis strukturalisme genetik memaparkan hubungan tokoh hero dengan tokoh yang lain dan juga menjelaskan relasi tokoh hero dengan tokoh lain, oposisi kultural, oposisi social, dan oposisi alamiah. Selain menganalisis strukturalimse genetik kemudian menganalisis kalimat atau penggalan kata untuk mencari ideologi teks.

Teknik pengumpulan data yang digunakan dalam penelitian ini adalah teknik pustaka, simak, dan catat. Teknik pustaka adalah teknik yang menggunakan sumber-sumber tertulis untuk memperoleh data (Subroto, 1992:42). Data penelitian diperoleh melalui studi pustaka dan teknik pembacaan semiotik tingkat pertama, yaitu pembacaan heuristik. Pembacaan secara heuristik berupa pemahaman makna sebagaimana dikonvensikan oleh bahasa.

Pada teknik pengumpulan data dengan membaca kritis secara terus menerus, mengamati, dan mengidentifikasi satuan-satuan bahasa yang terdapat dalam novel sesuai dengan tujuan peneliti. Setelah terkumpul, data diklasifikasi menurut jenis persoalan yaitu berdasarkan data strukturalisme genetik, dan ideologi.

\section{HASIL DAN PEMBAHASAN}

Pada bagian ini dibahas struktur teenlit karya Dyan Nuranindya, dan Ideologi teenlit karya Dyan Nuranindya.

Struktur teks yang akan di kaji dalam penelitian ini meliputi, relasi tokoh hero dengan tokoh lain, oposisi kultural, oposisi sosial, dan oposisi alamiah. Relasi tokoh hero dengan tokoh lain terbangun dari beberapa elemenelemen yang berhubungan atau berelasi. Sedangkan yang dimaksud dengan oposisi adalah perbandingan antara dua unsur untuk memperlihatkan perbedaan arti.

Relasi Tokoh Hero dengan Tokoh lain

Struktur teks teenlit karya Dyan Nuranindya berpusat pada tokoh utama atau tokoh hero. Terdapat enam tokoh hero dalam teenlit karya Dyan Nuranindya, yaitu (1) Karra (Dealova). (2) Keysha (Rahasia Bintang), (3) Melnie (Canting Cantiq), (4) Darra (Cinderela Rambut Pink), (5) Saka (Rock n Roll Onthel), dan (6) Aiko (Kotak Pelangi).

Relasi Adik dengan Kakak

Relasi adik dengan kakak dalam teenlit karya Dyan Nuranindya sangat kental. Dari enam teenlit terdapat tiga teenlit yang memiliki relasi adik dengan kakak. Ketiga teenlit tersebut adalah Dealova, Rahasia Bintang dan Rock N Roll Onthel. Relasi adik-kakak dalam teenlit Dealova. Karra sebagai tokoh utama memiliki seorang kakak laik-laki yang bernama Iraz. Mereka berdua sangat dekat hal tersebut terbukti dari kutipan dalam teenlit Dealova sebagai berikut.

Data (1) 
Hari ini Iraz dan anak-anak Blue Rivalry sedang makanmakan di salah satu restoran di daerah kemang. Maklum, mereka baru saja dapat honor dari manggung di festival band kemarin. Kalau urusan makan, Adit jelas paling bersemangat. Mereka juga mengajak Karra dan Manda, cewek Iraz. (DEA: 95)

Kutipan tersebut menunjukan kedekatan antara Iraz dan Karra. Karra diajak makan Bersama bandnya. Bukan hanya Karra yang diajak Iraz, tetapi Iraz juga mengajak Manda, pacar Iraz. Sebagai kakak yang dekat dengan kakaknya maka Iraz memperkenalkan Manda ke Karra.

Selanjutnya relasi adik kakak dalam teenlit Rahasia Bintang. Relasi antara Vano dan Keysha. Keysha sebagai tokoh utama memiliki seorang adik laki-laki bernama vano. Cara Vano menunjukan rasa perhatian terhadap kakaknya dengan cara menggoda dan ingin mengetahui tentang kehidupan Keysha.Hal itu ditunjukan dengan data sebagai berikut.

\section{Data (2)}

"Ngapain kamu cengar-cengir?" tanya Keysha sewot ngeliat adiknya yang menyebalkan itu. "abis pacarana, ya? Cowok itu ganteng juga. Selingkuhan elo, ya?" "uggh!!! Dia bukan selingkuhan aku tau! Kamu ngintip ya?" (RB:141)

Kutipan tersebut terjadi ketika Vano melihat kakaknya diantar seorang laki-laki. Vano mengintip dari balik jendela kakaknya diantar seoarang laki-laki. Tidak biasanya Keysha diantar pulang ke seorang cewek. Vano yang melihatnya langsung menggoda kakak perempuannya itu.

Relasi orangtua dengan anak

Relasi orangtua dengan anak dalam teenlit karya Dyan Nuranindya terdapat pada teenlit Rahasia Bintang, Canting Cantiq, Rock N Roll Onthel dan Kotak Pelangi. Relasi orangtua dengan anak yang terdapat dalam teenlit Rahasia Bintang hanya terjadi antara Ibu dengan anak. Hal tersebut karena Ibu Keysha telah bercerai dengan Ayahnya. Keysha tinggal bersama adik dan ibunya. Meskipun ibu Keysha adalah wanita karir dan orangtua tunggal namun dia tidak melupakan kewajiban sebagai seorang ibu untuk kedua anakanya. Hal tersebut dapat dilihat dari kutipan berikut.

Data (3)

"pagi, Kesya. Sarapan dulu gih. Ini Bunda buatin roti," ucap wanita itu sambil menyodorkan roti. "isi apa, Bun?" "biasa... selai stroberi kesukaan kamu." (RB:32)

Setiap pagi hari Keysha selalu disapa dengan lembut oleh ibunya. Ibunya memberikan sarapan kesukaan Keysha roti dengan selai stroberi. Meskipun ibunya kerja namun masih sempat membuatkan sarapan untuk anaknya. Sebagai orangtua tunggal ibu Keysha berusaha dekat dengan putrinya.

Relasi orangtua dengan anak selanjutnya terdapat dalam teenlit Canting Cantiq. Dalam teenlit ini pengrang menceritakan melanie sebagai took utama yang hanya memilki seorang ayah. Ibu melanie sudah lama meninggal dunia. Dalam teenlit CC pngarang menggambarkan hubungan ayah yang selalu memberikan yang terbaik untuk putrinya. Hal tersebut ditunjukan dengan kutipan sebagai berikut.

Data (4)
Papa memegang telapak tangan Mel mencoba menenangkan putrinya itu. "tolong kamu mengerti. Papa harus menyelesaikannya sendiri. Semua sudah Papa urus dengan pengacara Papa. Untuk sementara waktu kamu tinggal di rumah Eyang Santoso.” (CC:17)

Percakapan terjadi ketika ayah Mel sedang mengalami masalah keuangan. Perusahaan ayahnya sedang menagalami krisis. Semua asset milik ayahnya disita pihak Bank. Ayah Mel memutuskan supaya anaknya untuk sementara waktu tinggal di Jogja bersama eyangnya.

Relasi Cinta

Relasi cinta dalam teenlit merupakan bumbu-bumbu dalam teenlit. Semua teenlit karya Dyan Nuranindya terdapat relasi cinta. Relasi cinta selanjutnya terdapat dalam teenlit Rock N Roll Onthel. Tokoh utama dalam teenlit ini adalah Saka. Berikut kutipan relasi cinta dalam teenlit tersebut.

Data (5)

"lagu ini spesial untuk perempuan yang saya cintai. Perempuan yang begitu berani dan kuat. Malam ini di depan temen-temen semua, saya mau bilang..." Saka menghentikan kalimatnya. Ia melangkah ke arah Coro dan langsung menggenggam tangan cewek itu ke tengah panggung. "saya sayang kamu ....” (RRO:238)

Kutipan tersebut terjadi ketika grub band Saka selesai manggung. Saka tidak menutup konser tersebut melainkan mengambil alih mikrofon dan menyatakan perasaan kepada Coro, vokalis bandnya.

Kutipan relasi cinta terdapat dalam teenlit tersebut terjadi antara Aiko dan Ipank. Sudah lama Ipank mencintai Aiko namun Ipank tidak berani mengungkapkannya. Kutipan relasi cinta antara Aiko dan Ipank dibuktikan kutipan sebagai berikut.

Data (6)

Di tengah rasa sakit yang tak tertahankan Ipank tersenyum menatap Aiko. "aku.. nggak akan ngebiarin dia bawa kamu pergi, Ai.." air mata Aiko menetes. "kamu jangan banyak ngomong dulu..." Dia nangis. Sakura gue menangis memeluk gue. Bidadari itu mengeluarkan air matanya buat gue. Sebegitu berhargakah gue untuk dia? (KP:188)

Kutipan tersebut terjadi ketika Aiko sedang berjalan sendirian di kampus tiba-tiba ada yang menarik tangan Aiko untuk masuk ke dalam mobil. Tanpa sengaja Ipank melihat hal tersebut. Ipank langsung berlari dan berusaha menyelamatkan Aiko.

Ideologi Teenlit Dealova

Data (7)

Karra memang punya solidaritas yang tinggi. Dia nggak pernah pilih-pilih teman. Siapa pun dan dari status mana pun, pasti bisa dia temani selama dia merasa cocok sama orang tersebut. (DEA:12)

Pengarang menggambarkan sikap solidaritas Karra terhadap sesama. Pengarang memberikan konsep tentang seorang manusia merespon orang lain serta lingkungannya. Karra digambarkan seorang yang ramah dengan siapapun tanpa memperdulikan status sosial.

Ideologi Teenlit Rahasia Bintang 
Ideologi yang terdapat dalam teenlit Rahasia Bintang ditunjukan dengan kutipan berikut.

Data (8)

Mang Udin mengelap keringatnya "terkadang hidup itu memang membingungkan. Penuh pilihan dan kita dipaksa memilih satu yang terbaik. Saya cuma berharap semoga masalah neng Keysha ceat selesai..." Aji terdiam, merenungi kata-kata Mang Udin nggak sadar, kalau kata yang ia ucapkan barusan ternyata sangat berarti bagi Aji. "ngomong-ngomong, Mas Aji siapanya mbak Keysha?" Aji menunduk. Kemudian ia mengangkat wajahnya menatap Mang Udin. "saya... kakaknya." (RB: 279)

Percakapan tersebut terjadi antara Mang Udin (petugas kebersihan di stasiun) dengan Aji. Aji adalah pacar Keysha, namun karena ayah Aji dan Ibu Keysha akan menikah maka hubungan Keysha dan Aji tidak ungkin berlanjut. Hal tersebut membuat Aji frustasi dan mencoba menenangkan pikiran pergi ke stasiun tempat Keysha merenung jika sedang ada masalah. Di stasiun Aji bertemu dengan Mang Udin. Mang Udin bercerita tentang kehidupan yang penuh pilihan dan harus dipaksa untuk memilih satu pilihan. Hal tersebut membuat Aji sadar tentang hidup. Aji harus memilih tetap menjadi pacar Keysha atau menjadi kakak Keysha. Akhirnya Aji memilih menjadi kakak Keysha dan mengizinkan ayahnya menikah dengan ibu Keysha.

Ideologi Teenlit Canting Cantiq

Teenlit ini menceritakan perjuangan Melanie dalam mengejar cita-citanya. Cita-citanya harus kandas karena ayahnya meninggal dunia. Kutipan ideologi yang terdapat dalam teenlit teresbut sebagai berikut.

Data (9)

Bermodalkan wajah cantik dan tubuh yng bikin iri setiap cewek, Melanie banyak dilirik oleh agency-agency untuk tawaran foto majalah atau catwalk. Tapi saying, ia nggak pernah tertarik untuk jadi model local. Cita-citanyasejak kecil adalah jadi model Internasional. Ia yakin cepat atau lambat cita-citanya itu pasti terwujud. (CC:9)

Melanie gadis perkotan yang memiliki cita-cita menjadi model International. Remaja yang cerdas dan cantik yang memiliki cita-cita yang tinggi. Pengarang penggambarkan cita-cita yang tinggi patut untuk diperjuangkan dan diraih. Kutipan selanjunya merupakan pengalaman hidup Eyang santoso ketika muda.

Data (10)

"iya, Cuma tiga!" Eyang Santoso meyakinkan cucunya. Kemudian lelaki tua itu melanjutkan ceritanya. "setelah lulus sarjan, Eyang malahan suka keliling Indonesia untuk mengajar." "kenapa Eyang?" "karena Eyang pikir, buat apa kita sekolah tinggi-tinggi, buat apa kita punya gelar Panjangpanjang kalau kita ndak berada di tempat yang membutuhkan kita." "wah, kalau Presiden Indonesia tau, Eyang pantas dikasih gelar pahlawan tuh, Yang!" "gelar? Buat apa? Isin," jawab Eyang Santoso dengan logat Jawanya yang masih kental. Pandangan Eyang Santoso menerawang lagi. "saat ini, Eyang sedang berada di perjalanan akhir hidup Eyang. Gelar, kekuasaan, harta menjadi hal yang ndak penting lagi. Yang repenting saat ini bagi Eayng adalah bagaimana Eyang mempergunakan sisa umur Eyang untuk hal yang lebih bermanfaat bagi generasi penerus.." (CC:69)

Masa muda eyang penuh dengan pengabdian terhadap bangsa dan negara. Hal tersebut terbukti dari percakapan di atas antara Melanie dengan eyang. Pengarang memberikan pandangan tentang sekolah tingi-tinggi harus menjadi orang yang berguna, bermanfaat untuk orang.

Kutipan selanjutnya tentang pandangan pengarang tentanng batik merupakan karya seni budaya iandonesia.

Data (11)

"kamu tau tidak, batik itu salah satu karya seni budaya Indonesia yang telah diakui secara Internasional. Meskipun begitu, hanya ada segelintir orang yang mampu melakukan pekerjaan membatik. Merekalah orang-orang yang memiliki kemampuan untuk membuat batik. Perlu konsentrasi dan cita rasa seni yang tinggi untuk membuat satu kain batik. Jangan kamu anggap remeh pekerjaan tersebut. (CC:114)

Pengarang membuka wawasan tentang batik Indonesia. Pengarang memberkan gambaran bahwa seni membatik adalah seni tingkat tinggi. Tidak semua orang bisa membatik, hanya orang tertentu yang mampu membuat batik.

Kutipan berikut terjadi ketika Melanie berkunjung ke galeri Aryati Sastra.

Data (11)

Mel merasa kepalanya mulai senat-senut. Pusing mendengarkan Aryati Sastra yang panjanng-lebar menjelaskan proses pembuatan batik. Tapi dalam hati Mel heran juga. Ternyata kain yang selama ini dia anggap kuno ternyata bikinya susah banget. Tapi tetap saja dia heran. Mana mungkin kain kuno seperti itu bisa go Internasional? Agnes Monica yang kerennya kayak gitu aja perlu bersusah payah untuk go Internasional. Aryati Sastra pasti bohong. "kamu tahu tidak, Adidas saja sudah menggunakan batik sebagai motif opinya. Marriah Carey juga punya gaun batik. Bill Clinton, Nelson Mandela, dan selebriti red carpet banyak yang mengagumi dan memakai kain batik buatan Indonesia. Seharusnya kamu bangga menjadi orang Indonesia, Melanie..." (CC:115)

Pengarang memberikan wawasan tentang buadaya Indonesia, yaitu tentang kain batik. Batik sebagai warisan dunia harus tetap dilestarikan oleh kaum muda. Pemuda Indonesia harus bangga dengan batik Indonesia yang sudah mendunia.

Kutipan berikutnya terjadi ketika Melanie berhasil menjadi desainer baju. Dia memberikan merek yang ada unsur batiknya agar terkesan buatan Indonesia.

Ideologi Teenlit Cinderela Rambut Pink

Teenlit Cinderela Rambut Pink mengambarkan ideologi pengarang tentang cita-cita Oscar.

Data (12)

Oscar Montaimana. Fotografer muda berbakat dari Indonesia yang tidak pernah mengambil Pendidikan fotografi secara formal," ucap Beno. Beno menganggukanggukkan kepala. "di situ tertulis bahwa Oscar Montaimana adalah fotografer freelance yang banyak dipakai di majalahmajalah luar negeri karena taste fotografinya yang tinggi. Semua hasil fotonya sanggup bercerita sendiri." 
Oscar memiliki hobi fotografi namun dilarang oleh orangtuanya karena menganggap bahwa fotografi bukanlah pekerjaan yang mengahasilkan uang, Oscar membuktikan kepada orangtuanya bahwa fotografi dapat menghasilkan sesuatu. Oscar tidak pernah menempuh sekolah formal di bidang fotografi mampu membuktikan kehebatannya dengan menjadi fotografer di majalah-majalah luar negeri.

Ideologi Teenlit Rock N Roll Onthel

Pengarang memberikan pandangan tentang sekolah musik yang dicita-citakan Saka.

Data (13)

Bapak memang sempat sekolah seni di Jepang. Tapi hal itu tidak membuat beliau terpengaruh budaya negeri sakura tersebut. Jiwa nasionalisme Bapak patut diacungi dua jempol. Kecintaanya terhadap sejarah dan budaya Indonesia selalu berusaha ia tularkan kepada anak-anaknya. (RRO:20)

Ayah Saka seorang dalang terkenal dan pernah sekolah di Jepang. Meskipun beliau pernah sekolah di Jepang, beliau tidak terpengaruh budaya Jepang. Pengarang memberikan pemahaman tentang seni wayang yang harus tetap dilestarikan secara turun temurun.

Ideologi teenlit Kotak Pelangi

Ideologi pengarang yang terdapat dalam teenlit Kotak Pelangi adalah mencintai alam dan menjaga kebersihan alam.

Data (14)

"Kita mau turun jam berapa, pank?" ucapnya memecah keheningan. "setengah delapan aja, yuk. Pengen nyebur ke danau." "wah, cakep tuh." "iya, tapi sampah jangan sampai lupa dibawa turun lagi!" Ah, itu sih beres, Bos!asal jangan hati yang lupa dibawa aja. (KP:17-18)

Ipank adalah ketua Mapala di kampusnya. Ipank sering naik gunung untuk menikmati keindahan alam. Ipank mendaki gunung dengan membawa kembali sampahsampahnya.

\section{SIMPULAN DAN SARAN}

Berdasarkan tahapan penelitian yang telah dilakukan, maka dapat disimpulkan hasil penelitian teenlit karya Dyan Nuranindya mencakupi struktur karya sastra teenlit karya Dyan Nuranindya meliputi relasi toko hero dengan tokoh yang lain, dan relasi oposional. Relasi tokoh hero denga tokoh yang lain meliputi relasi adik kakak, relasi orangtua dengan anak, relasi cinta. Ideologi yang terdapat dalam teenlit karya Dyan Nuranindya adalah meraih cita-cita, cinta tanah air, menjaga kelestarian alam.

\section{DAFTAR PUSTAKA}

Althusser, Louis. (1971). Essays on Ideology. London: Verso.

Nuranindya, Dyan. (2004). Dealova. Jakarta: Gramedia Pustaka.

Nuranindya, Dyan. (2006). Rahasia Bintang. Jakarta: Gramedia Pustaka.

Nuranindya, Dyan. (2009). Canting Cantiq. Jakarta: Gramedia Pustaka.
Nuranindya, Dyan. (2010). Cinderella Rambut Pink. Jakarta: Gramedia Pustaka.

Nuranindya, Dyan. (2012). Rock $n$ Roll Onthel. Jakarta: Gramedia Pustaka.

Nuranindya, Dyan. (2014). Kotak Pelangi. Jakarta: Gramedia Pustaka.

Noor, Redianto. (2014). "Profil Penerbit Novel Chicklit dan Teenlit Indonesia". Humanika, vol. 2 (2) hal, 82-89.

Ratna, Nyoman Kutha. (2009). Stilistika: kajian puitika bahasa, sastra, dan budaya. Yogyakarta: Pustaka Pelajar.

Subroto. (1992). Penelitian Kualitatif. Jakarta: Raja Grafindo Persada.

Sumardjo, Jakob. (1982). Novel Populer Indonesia. Yogyakarta: Nur Cahaya. 